\title{
MAPPING OF THE Hor2 LOCUS IN BARLEY BY PULSED FIELD GEL ELECTROPHORESIS
}

\author{
by \\ MIKAEL BLOM SØRENSEN \\ Department of Physiology, Carlsberg Laboratory, \\ Gamle Carlsbergvej 10, DK-2500 Copenhagen Valby \\ and \\ Institute of Genetics, University of Copenhagen, \\ Øster Farimagsgade 2A, DK-1353 Copenhagen K.
}

Keywords: Hordeum vulgare L., B-hordein polypeptides, storage protein, protoplasts

\begin{abstract}
High molecular weight DNA released from isolated protoplasts was digested with rare-cutting restriction enzymes and separated by pulsed field gel electrophoresis. The average size of undigested DNA was above 1500 $\mathrm{kbp}$. Digests made with NotI, Sfil, MluI and Sall was hybridized to a probe, common to all genes of the Hor 2 locus encoding B-hordein polypeptides, and this revealed the maximum size of the locus to be $360 \mathrm{kbp}$. Two probes, specific for individual B-hordein genes, enabled the identification of two fragment classes in the locus, each containing an equal number of B-hordein genes. Double digests allowed ordering of sites and construction of a map covering $650 \mathrm{kbp}$ around the Hor 2 locus. No evidence for physical linkage of the two fragment classes was obtained. The possible assignment of the two classes of hybridizing fragments to the B1- and B3-hordein subgroups is discussed.
\end{abstract}

\section{INTRODUCTION}

In barley the major groups of storage proteins, the B-, C- and D-hordein polypeptides, are encoded by complex genetic loci on chromosome 5, called Hor2, Hor 1 and Hor3, respectively $(1,23,40)$. SDS gel electrophoresis reveals polymorphism of B- and C-hordein, while Dhordein migrates as a single band. On the basis of migration rates B-hordein is divided into $\mathbf{B} 1$, B2 and B3 type polypeptides, and two-dimensional electrophoresis has shown that each of these groups contain a number of polypeptides
(14). The Hor2 locus has been estimated to contain at least 13 copies of B-hordein genes (25), accounting for the polymorphism in the polypeptides. Horl is less complex than Hor2 (35), while Hor 3 only contains 1-2 genes. The genes encoding the $\gamma$-hordein polypeptides, a minor storage protein group (39), constitute another small multigenic family in barley (7). $H r d F$, a locus located very close to Hor2 (29), has recently been shown to encode at least some $\gamma$-hordein polypeptides (41).

A more detailed analysis of the arrangement

Abbreviations: $\mathrm{bp}=$ basepair; HMW $=$ High Molecular Weight; $\mathrm{kbp}=$ kilobasepair; OFAGE $=$ Orthogonal Field Alternation Gel Electrophoresis; PFGE = Pulsed Field Gel Electrophoresis; RFLP = Restriction Fragment Length Polymorphism. 
of genes within the complex hordein loci and, if possible, of the chromosomal organization of neighboring loci will thus provide the basis for new information on both regulatory and evolutionary aspects of the hordein genes.

During endosperm development the hordein genes are coordinately expressed from approximately 8 days after anthesis (43), but differential expression of B- and C-hordein and of B1- and B3-hordein has been observed (33). Furthermore, hordein mRNA levels respond differentially to changed levels of nutrients, C-hordein being preferentially expressed relative to $\mathrm{B}$ hordein with increasing concentrations of nitrogen (19). A possible connection between this differential regulation of expression and the clustering of the hordein genes in multigenic loci has yet to be proven.

The current knowledge on large scale chromosomal arrangement of multigenic families in plants is very sparse. In contrast, stretches of up to $10,000 \mathrm{kbp}$ of human chromosomes have been physically mapped. The methods that have made this extensive mapping possible are the techniques for separation of very large DNA molecules (PFGE) developed by SCHWARTZ and CANTOR (38) and CARLE and OLSON (8). DNA molecules larger than $6,000 \mathrm{kbp}$ can be separated with PFGE (42) and the technique has enabled separation of intact yeast chromosomes from S. cerevisiae (9) and S. pombe (42). In humans, PFGE has been used to study multigene families, for example the major histocompatibility complex (HLA) (26) and particular chromosomal regions such as the pseudoautosomal (homologous) region near the telomeres of the $X$ and $Y$ chromosomes $(4,34)$. The 2,000 kbp Duchenne muscular dystrophy gene has been intensely studied by PFGE and a map of $10,000 \mathrm{kbp}$ of surrounding chromosomal regions has been constructed (6).

Together with the establishment of detailed RFLP maps and construction of jumping and linking libraries $(31,32)$ the use of PFGE is also anticipated to facilitate the cloning of hitherto unaccessible genes, since these techniques allow rapid genomic walking from a linked RFLP marker towards the gene of interest. This approach is however dependent on some means of identifying the desired gene.
In the present study methods for isolation and digestion of high molecular weight barley DNA were developed and PFGE was used to construct a map of the Hor2 locus.

\section{MATERIALS AND METHODS}

\subsection{Plant Material}

Protoplasts were isolated from the etiolated leaves of 6-8 days old dark-grown barley (Hordeum vulgare L. cv. Carlsberg II) seedlings.

\subsection{Chemicals}

Cellulase $\mathrm{Y}-\mathrm{C}$, and Macerozyme $\mathrm{R} 10$ was obtained from Seishin Pharmaceutical Co. Ltd. (Japan) and Yakult Honsha Co. Ltd. (Japan) respectively. Pronase and all restriction enzymes except SfiI were from Boehringer Mannheim. SfiI was obtained from New England Biolabs, Inc. The low gelling temperature agarose was SeaPlaque and normal agarose was SeaKem GTG both from FMC BioProducts (Maine, USA). Nylon membranes was GeneScreen Plus from Du Pont (New England Nuclear). Radiolabelling of probes was performed with a kit from Boehringer Mannheim, and radiolabelled nucleotides were obtained from Du Pont (New England Nuclear). The film used for autoradiography was Kodak X-Omatic AR.

\subsection{Protoplast isolation}

Protoplasts were isolated by a procedure modified from EDWARDS et al. (13). Approximately $12 \mathrm{~g}$ of freshly harvested leaf material was homogenized in sorbitol buffer $(0.5 \mathrm{M}$ sorbitol, $1 \mathrm{mM} \mathrm{CaCl}_{2}, 5 \mathrm{~mm}$ MES-KOH, pH 5.5) with a modified kitchen homogenizer (24), until the average size of the leaf pieces was around $1 \mathrm{~mm}^{2}$. The material was transferred in $100 \mathrm{ml}$ of sorbitol buffer to two petri dishes $(14 \mathrm{~cm})$ and incubated without agitation for $4-5 \mathrm{~h}$ at $30^{\circ} \mathrm{C}$ with $1 \%$ cellulase $\mathrm{Y}-\mathrm{C}$ and $0.2 \%$ Macerozyme R10. The protoplasts were separated from vascular strands and larger debris by filtration through a $200 \mu \mathrm{m}$ nylon mesh and pelleted from the enzyme solution by centrifugation $(100 \times \mathrm{g}$ for $5 \mathrm{~min}$ ). To achieve further purification the protoplasts were resuspended in sucrose buffer 
(0.5 M sucrose, $1 \mathrm{mM} \mathrm{CaCl}_{2}, 5 \mathrm{mM}$ MES-KOH, $\mathrm{pH}$ 5.5), overlayered with a 1:4 mixture of sorbitol and sucrose buffer and thereafter with sorbitol buffer. After centrifugation $(150 \times \mathrm{g}$ for 5 $\mathrm{min}$ ) the intact protoplasts were recovered from the interphase of the sorbitol:sucrose buffer and the sorbitol buffer. The protoplasts were counted in a hemacytometer, pelleted ( $200 \times \mathrm{g}$ for $5 \mathrm{~min}$ ) and resuspended in sorbitol buffer at a concentration of $3 \times 10^{7}$ cells $/ \mathrm{ml}$.

For the preparation of HMW DNA the protoplast suspension was warmed to $37{ }^{\circ} \mathrm{C}$ and mixed with an equal volume of melted $1 \%$ low gelling temperature agarose at $37^{\circ} \mathrm{C}$, made up in sorbitol buffer with $20 \mathrm{~mm}$ Tris- $\mathrm{HCl} \mathrm{pH}$ 8.5. The mixture was poured into a plug mould and allowed to set on ice for $10 \mathrm{~min}$. To release HMW DNA from the protoplasts, the plugs were incubated in NDS (0.5 M EDTA, 1\% lauroyl sarcosine, $10 \mathrm{~mm}$ Tris, adjusted to $\mathrm{pH} 9.5$ with $\mathrm{NaOH}$ ) with $1 \mathrm{mg} / \mathrm{ml}$ pronase for $48 \mathrm{~h}$ at $50^{\circ} \mathrm{C}$, with a change of buffer and enzyme after $24 \mathrm{~h}$ (4). Finally, the plugs were washed three times for $2 \mathrm{~h}$ at $4{ }^{\circ} \mathrm{C}$ with NDS without pronase and then stored in NDS at $4{ }^{\circ} \mathrm{C}$.

\subsection{Digestion of DNA in agarose}

Prior to digestion each plug, containing approximately $10 \mu \mathrm{g}$ DNA from $6 \times 10^{5}$ protoplasts, was washed 3 times with $1 \mathrm{ml} \mathrm{TE}(10 \mathrm{~mm}$ Tris- $\mathrm{HCl}, 1 \mathrm{~mm}$ EDTA, $\mathrm{pH} 7.5$ ) for $30 \mathrm{~min}$ at 0 ${ }^{\circ} \mathrm{C}$. The plug was then equilibrated in $0.5 \mathrm{ml}$ of the appropriate restriction buffer for $30 \mathrm{~min}$ at $0{ }^{\circ} \mathrm{C}$. The restriction buffer was exchanged with $60 \mu \mathrm{l}$ of restriction buffer containing $100 \mu \mathrm{g} / \mathrm{ml}$ gelatin and after $5 \mathrm{~min}$ at room temperature restriction enzyme was added. The samples were incubated for $1 \mathrm{~h}$ at the appropriate temperature, at which time another aliquot of restriction enzyme was added and the incubation continued for 1 to $3 \mathrm{~h}$. After the digestion the restriction buffer was removed and the plug was equilibrated for $15 \mathrm{~min}$ in $0.5 \times \mathrm{TBE}(10 \times \mathrm{TBE}$ is: $0.89 \mathrm{M}$ Tris-borate, $0.89 \mathrm{M}$ boric acid, $2 \mathrm{mM}$ EDTA, pH 7.5) before loading on a gel.

\subsection{Pulsed field gel electrophoresis}

HMW DNA was electrophoretically separated on either an OFAGE apparatus (8) or a
'Waltzer' apparatus as described by SOUTHERN et al. (44) with the difference that the electrodes were rotated and not the gel. Both machines were built by the Carlsberg laboratory workshop and controlled by a FESTO FPC201 programmable controller. The conditions for electrophoresis were $9 \mathrm{~V} / \mathrm{cm}$ for $32 \mathrm{~h}$ in $0.5 \times \mathrm{TBE}$ at $14{ }^{\circ} \mathrm{C}$ with an agarose concentration of $1.5 \%$, unless otherwise stated. The pulse length is indicated in the individual figures. DNA size markers in the electrophoresis were yeast chromosomes (Saccharomyces cerevisiae X21801B) and oligomers of Lambda DNA both prepared according to SOUTHERN et al. (44).

\subsection{DNA transfer and hybridization}

The gel was incubated in $0.25 \mathrm{M} \mathrm{HCl}$ for $2 \times 12$ $\min$ and $0.5 \mathrm{M} \mathrm{NaOH}, 1.5 \mathrm{M} \mathrm{NaCl}$ for $2 \times 15 \mathrm{~min}$ to depurinate and denature the DNA. The DNA was transferred to nylon membranes by alkaline blotting (37). Prehybridization and hybridization were performed for 2 and $16 \mathrm{~h}$, respectively, at $65{ }^{\circ} \mathrm{C}$ in $2 \times \mathrm{SSP}(0.3 \mathrm{M} \mathrm{NaCl}, 0.02 \mathrm{M}$ $\left.\mathrm{NaH}_{2} \mathrm{PO}_{4}\right), 10 \times$ Denhardt's solution $(2 \mathrm{mg} / \mathrm{ml}$ Ficoll, $2 \mathrm{mg} / \mathrm{ml}$ polyvinylpyrrolidone, $2 \mathrm{mg} / \mathrm{ml}$ BSA), $1 \%$ SDS, $50 \mu \mathrm{g} / \mathrm{ml}$ sheared salmon sperm DNA and $50 \mu \mathrm{g} / \mathrm{ml}$ polyA. Probes were labelled with ${ }^{32} \mathrm{P}$-dATP (3000 Ci/mmole) using random hexanucleotide priming (15) to a specific activity of $0.5-2 \times 10^{9} \mathrm{cpm} / \mu \mathrm{g} \mathrm{DNA}$, and added to the hybridization solution at a concentration of 1-5 $\mathrm{ng} / \mathrm{ml}$. Filters were washed with $2 \times \mathrm{SSP}, 1 \%$ SDS at $65^{\circ} \mathrm{C}$ and exposed at $-80^{\circ} \mathrm{C}$ for 1 to 14 days. Before rehybridizing the probe was removed from the filters by washing at $37{ }^{\circ} \mathrm{C}$ in $0.4 \mathrm{M}$ $\mathrm{NaOH}$ for 30 min and neutralized in $0.1 \times \mathrm{SSP}$, $0.1 \%$ SDS and $0.2 \mathrm{M}$ Tris-HCl, pH 7.5 at $37^{\circ} \mathrm{C}$ for $30 \mathrm{~min}$.

\section{RESULTS}

\subsection{Isolation of probes}

The 720 bp insert from pchor2-4, a B-hordein cDNA clone (36), cross-hybridizes to all Bhordein genes under the conditions described in materials and methods, and was therefore selected as a probe to identify the Hor 2 locus. In order to identify individual fragments of the Hor2 


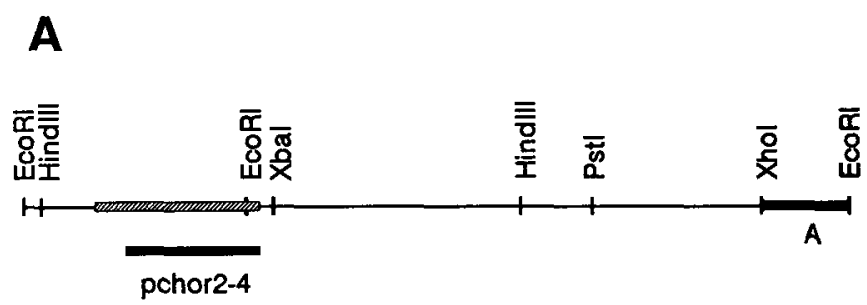

B

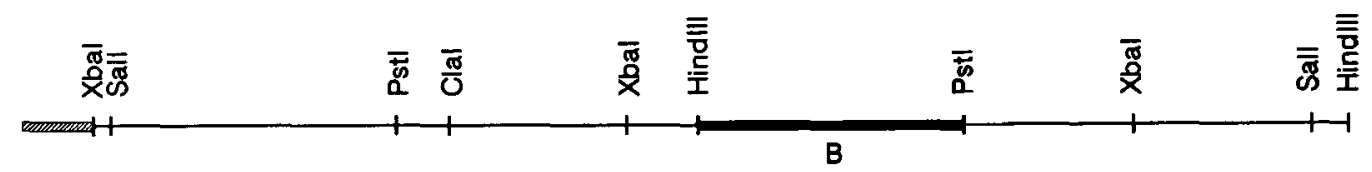

Figure 1. Map of the genomic $\lambda$ clones A: $\lambda$ hor $2-4$ and $B: \lambda$ hor $2-2$. The hatched areas indicate coding regions, while the filled areas represent the restriction endonuclease fragments isolated for probes. The part of the hor $2-4$ coding region covered by the cDNA clone pchor2-4 is indicated below $\lambda$ hor $2-4$.

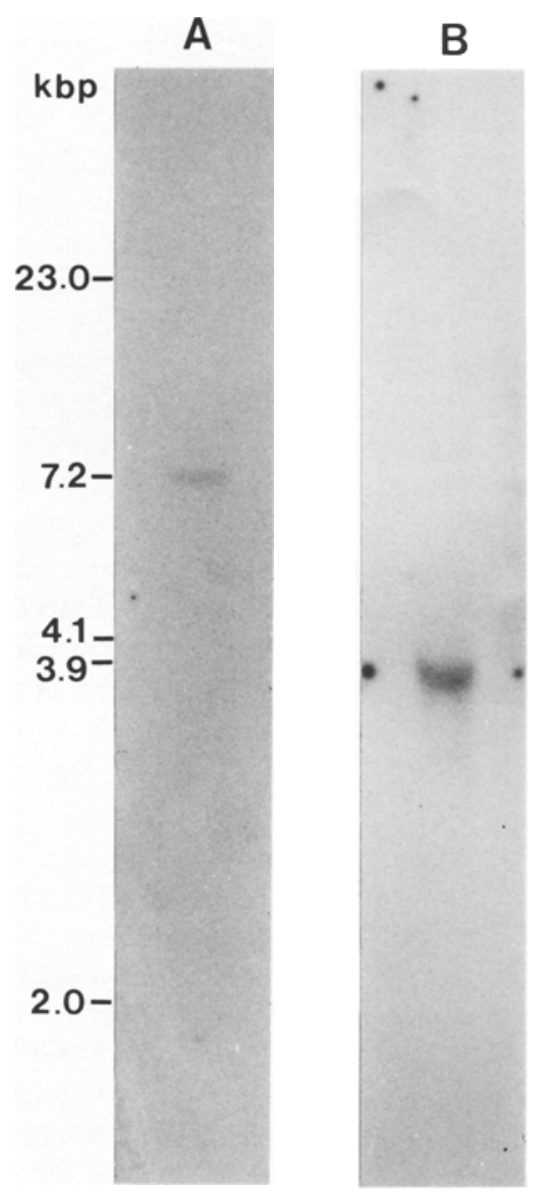

locus two probes specific for single B-hordein genes were isolated. The first of these is a $0.5 \mathrm{kbp}$ EcoRI-Xhol fragment positioned $2.5 \mathrm{kbp}$ downstream of the B-hordein coding region in the genomic clone $\lambda$ hor $2-4$ (3). The other is a 1.5 kbp HindIII-PstI fragment located $3.4 \mathrm{kbp}$ downstream of the coding region in the Bhordein genomic clone $\lambda$ hor2-2 (BRENNER et al., unpublished). The origin of the three probes is given in Figure 1, the probe from $\lambda$ hor $2-4$ is called $A$ and the probe from $\lambda$ hor $2-2$ is B. To ascertain their specificity the probes A and B were hybridized to HindIII digested barley DNA. Probe A hybridizes to a fragment of approximately $7 \mathrm{kbp}$ (Fig. 2A), while probe B hybridizes to a $4 \mathrm{kbp}$ fragment as expected from the restriction map of this clone (Fig. 2B). Both probes hybridize with the intensity expected of a single copy probe. In contrast, the cDNA probe

Figure 2. Southern blots of genomic barley DNA digested with HindIII. Hybridization was in A with the $\lambda$ hor2-4 specific probe and in $B$ with the $\lambda$ hor2-2 specific probe. HindIII digested $\lambda g t$ wes $/ \lambda B$ was used as size marker. Conditions for the electrophoresis were $0.7 \%$ agarose, $5 \mathrm{~V} / \mathrm{cm}$ for $16 \mathrm{~h}$ in $1 \times \mathrm{TBE}$, blotting and hybridization as described in materials and methods (2.6). 


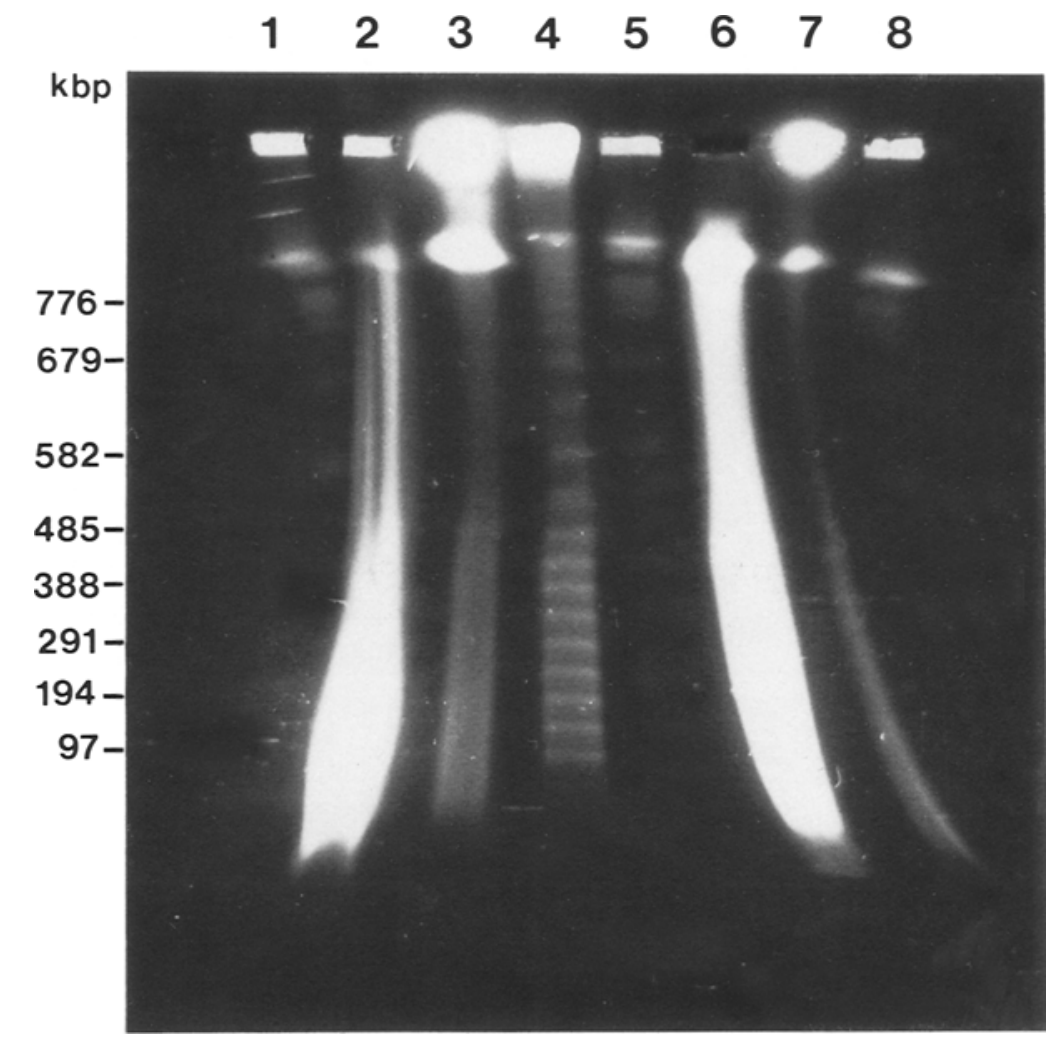

Figure 3. Ethidium bromide stained OFAGE gel of HMW barley DNA. Pulse length: 55 sec. The gel was run with $15 \mathrm{~V} / \mathrm{cm}$ for $24 \mathrm{~h}$. Lanes 1,5 and 8 contain yeast chromosomes, lane $4 \lambda$ oligomers and lanes 2,3 and $6 \mathrm{HMW}$ barley DNA digested with MluI (lane 2), NaeI (lane 3) or Sall (lane 6). Lane 7 is an undigested control incubated at $37^{\circ} \mathrm{C}$ with restriction buffer but without enzyme.

gives 8-9 hybridizing fragments between 3 and $25 \mathrm{kbp}(3)$.

\subsection{Isolation and digestion of HMW DNA}

Since HMW DNA is a prerequisite for the application of PFGE, barley DNA was prepared by different methods and examined by OFAGE to determine the size distribution of DNA molecules. Protoplasts were isolated and the DNA released as described in materials and methods (2.3). Undigested DNA from these protoplasts was separated by OFAGE (Fig. 3, lane 7). The majority of the DNA is retained in the slot, while a faint smear is seen, ranging from $50 \mathrm{kbp}$ to above $1000 \mathrm{kbp}$. Thus, protoplasts are a suitable starting material for the isolation of HMW barley DNA. DNA prepared by phenol extraction and $\mathrm{CsCl}$ gradient centrifugation (21) is largely of a size between 100 and $300 \mathrm{kbp}$ (results not shown). Alternatively, DNA was recovered from isolated nuclei (43) which were embedded in agarose and incubated in $0.5 \mathrm{M}$ EDTA, $1 \%$ lauroyl sarcosine with $1 \mathrm{mg} / \mathrm{ml}$ proteinase $\mathrm{K}$ to lyse the nuclei and degrade the proteins. This DNA gives two fractions containing similar amounts of DNA. One fraction fails to migrate at all, indicating a size above 1500 $\mathrm{kbp}$, while the other is degraded to between 100 and $1000 \mathrm{kbp}$ (results not shown). Hence, neither standard procedures nor isolated nuclei yields DNA sufficiently intact for PFGE. Analysis of different DNA preparations from tomato (10) and Arabidopsis (20) by PFGE gave similar results. 
Since approximately $6 \times 10^{5}$ protoplasts are required for one DNA digestion, an easy isolation method with relatively high yields is a necessity. The protoplast isolation method employed here, routinely yields $1-2 \times 10^{6}$ protoplasts/ 8 of barley leaves and can easily be scaled up by to starting with $30-40 \mathrm{~g}$. Other methods give higher yields, $3-6 \times 10^{6}$ protoplasts $/ g(22$, 30 ), but require lengthy preparation of the leaves, such as peeling off the epidermis.

A number of potentially rare-cutting restriction enzymes were tested for their ability to digest HMW barley DNA. Successful digests were made with NotI, SfiI, SalI and MluI, while
NaeI, SacIl and RsrII were not able to produce visible digestion or hybridizing fragments. Restriction with $2 \times 40$ units of MluI, NotI or Sfil as described in materials and methods, reaches a maximum after $4 \mathrm{~h}$. Increased amount of enzyme or longer incubation time have no further effect. However, Sall digestion with $2 \times 10$ units appears to be complete. A variable portion of the DNA is not resolved after digestion with MluI (Fig. 3 lane 2), Notl and Sfil. This portion hybridizes to the probes used with varying intensity. Due to the variation it is concluded that this fraction is not comprised of large unresolved fragments but rather a random portion of the

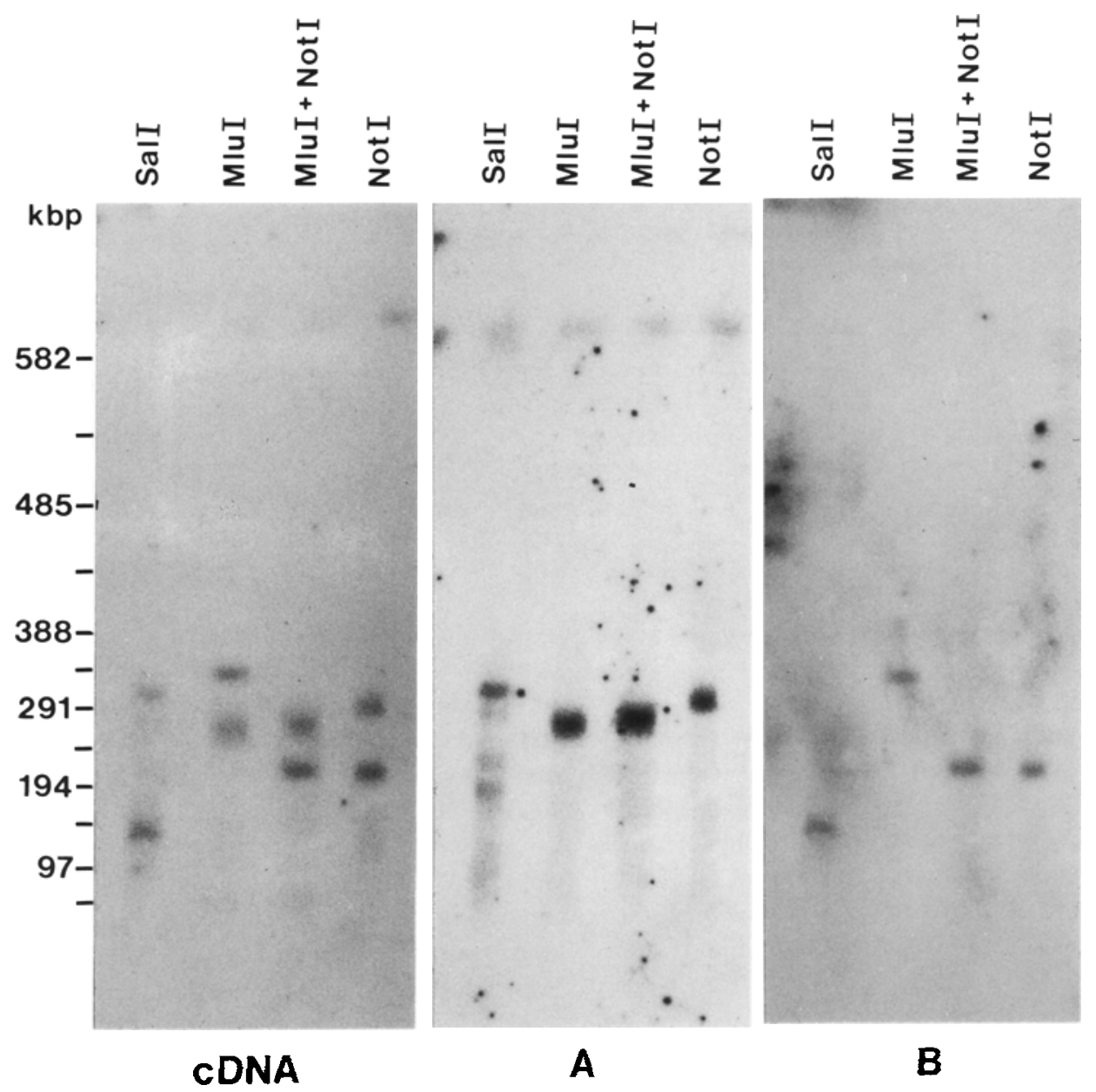

Figure 4. 'Waltzer' analysis of HMW barley DNA digested with Sall, MluI, Notl and NotI + MluI as indicated in the lanes. The gel was blotted and successively hybridized with pchor $2-4 \mathrm{cDNA}$ probe, probe $\mathrm{A}$ and probe $\mathrm{B}$ as indicated in Figure 1. Pulse length: $40 \mathrm{sec}$. 


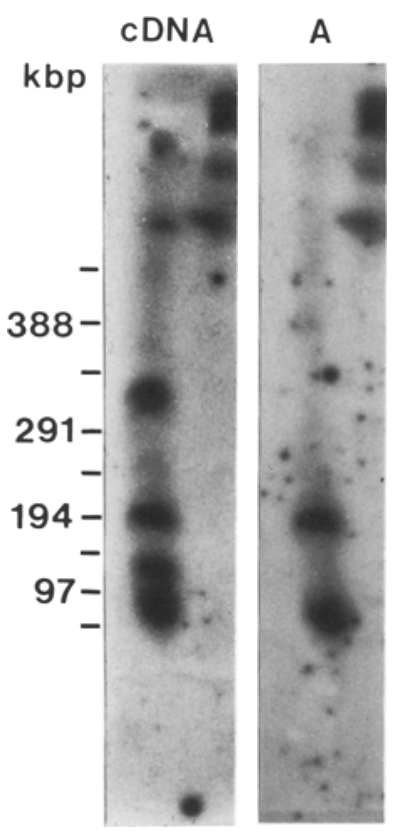

Figure 5. OFAGE analysis of HMW barley DNA digested with Sfil. Hybridization with pchor 2-4 CDNA probe and probe $A$ as indicated in Figure 1. Pulse length: $30 \mathrm{sec}$.

DNA, which is inaccessible to digestion.

While MluI (Fig. 3, lane 2) and SfiI digested DNA ranges from less than $50 \mathrm{kbp}$ to approximately $500 \mathrm{kbp}$, digestion with SalI (Fig. 3, lane 6) and NotI produces a smear ranging from $50 \mathrm{kbp}$ to above $1000 \mathrm{kbp}$ and the NaeI (Fig. 3, lane 3), SacII and RsrII digests resemble the undigested control.

\subsection{Mapping of the Hor2 locus}

Digests' were blotted and hybridized with the B-hordein cDNA probe. At least two hybridizing fragments were found in each restriction digest. Digestion with NotI gives two strongly hybridizing fragments of 300 and $230 \mathrm{kbp}$ (Fig. 4). In the MluI digest three fragments appear, two fragments at 345 and $270 \mathrm{kbp}$, and a fragment of less than $50 \mathrm{kbp}$ giving a weak signal (Fig. 4). The $270 \mathrm{kbp}$ fragment is quite diffuse and resolves into two fragments of 280 and 260 $\mathrm{kbp}$, when the pulse length is decreased from 40 to 30 seconds (Fig. 6). Sfil digestion results in four fragments of 70, 120, 200 and $330 \mathrm{kbp}$ (Fig. 5), which hybridize with similar intensities. SalI gives two strongly hybridizing fragments of 325 and $160 \mathrm{kbp}$ (Fig. 4) and 3-4 fragments, which range in size from 120 to $290 \mathrm{kbp}$, and show weak and variable hybridization intensity.

Restriction enzymes sensitive to methylated cytosine (e.g. SalI) may give partial cleavage at certain sites due to incomplete methylation of the DNA, and Sfil has also been reported to produce partial digestion at certain sites (12), although this enzyme apparently is insensitive to methylation of the recognition site (27). In order to determine whether some or all of the hybridizing fragments are the result of partial digestion, hybridizations were repeated with the two gene specific probes.

Only the larger of the two NotI hybridizing fragments, seen with the coding region probe, hybridizes to probe $A$, while probe $B$ hybridizes to the smaller NotI fragment (Fig. 4). This clearly indicates that the two fragments are not the result of a partially cleaved NotI site, but represent individual sequences containing different B-hordein genes. With the three other enzymes some of the observed fragments can be ascribed to partial digestion, but all three yield fragments hybridizing to only one or the other of the two gene specific probes. In the Sall digest, probe A hybridizes to the $325 \mathrm{kbp}$ fragment but also to the smaller and less strongly hybridizing fragments (Fig. 4). The $325 \mathrm{kbp}$ Sall fragment must therefore contain 3-4 partially methylated SalI sites. Only the $160 \mathrm{kbp}$ Sall fragment hybridizes to probe B (Fig. 4). Both the 70 and $200 \mathrm{kbp}$ Sfil fragments hybridize to probe $\mathrm{A}$ (Fig. 5), and consequently the $200 \mathrm{kbp}$ fragment must contain a partially cleavable SfiI site, which upon cleavage divides the fragment into 120 and $70 \mathrm{kbp}$ fragments. In a similar way the $280 \mathrm{kbp}$ MluI fragment is partially digested into a $260 \mathrm{kbp}$ fragment hybridizing to probe A (Fig. 6 ) and a small ( $<50 \mathrm{kbp}$ ) fragment, which only hybridizes to the cDNA probe (Fig. 6).

Double digests were needed to map these restriction sites relative to the probes and Hor 2 . The production of double digests was difficult due to the apparently incomplete digestion observed in NotI, MluI and SfiI digests. Successful double digests were only obtained with 
NotI+MluI and SalI+MluI. These give no new fragments hybridizing to the coding region of B-hordein (Figs. 5, 6), so that only the order of sites and not the distance between them can be determined. Thus, the $345 \mathrm{kbp}$ MluI fragment contains two NotI sites, giving the $230 \mathrm{kbp}$ NotI fragment, where the hybridizing sequences are located. Similarly, the $300 \mathrm{kbp}$ NotI fragment must contain three MluI sites, one of which is partially cleaved, giving the 280 and $260+<50$ kbp MluI fragments. The fragments in the double digests appear slightly larger than the corresponding fragments in the single digests. This can be explained by differences in migration rate caused by local differences in DNA concentration. This phenomenon has previously been observed during analysis of human DNA by PFGE (28).

All the identified fragments can be divided into two classes, one class hybridizing to the hor $2-2$ probe and the other to the hor $2-4$ probe. The double digests provide no evidence of an overlap between these two classes. Some indication of the distance between these two classes might be gained from partial digests. Identification of a partially digested fragment hybridizing
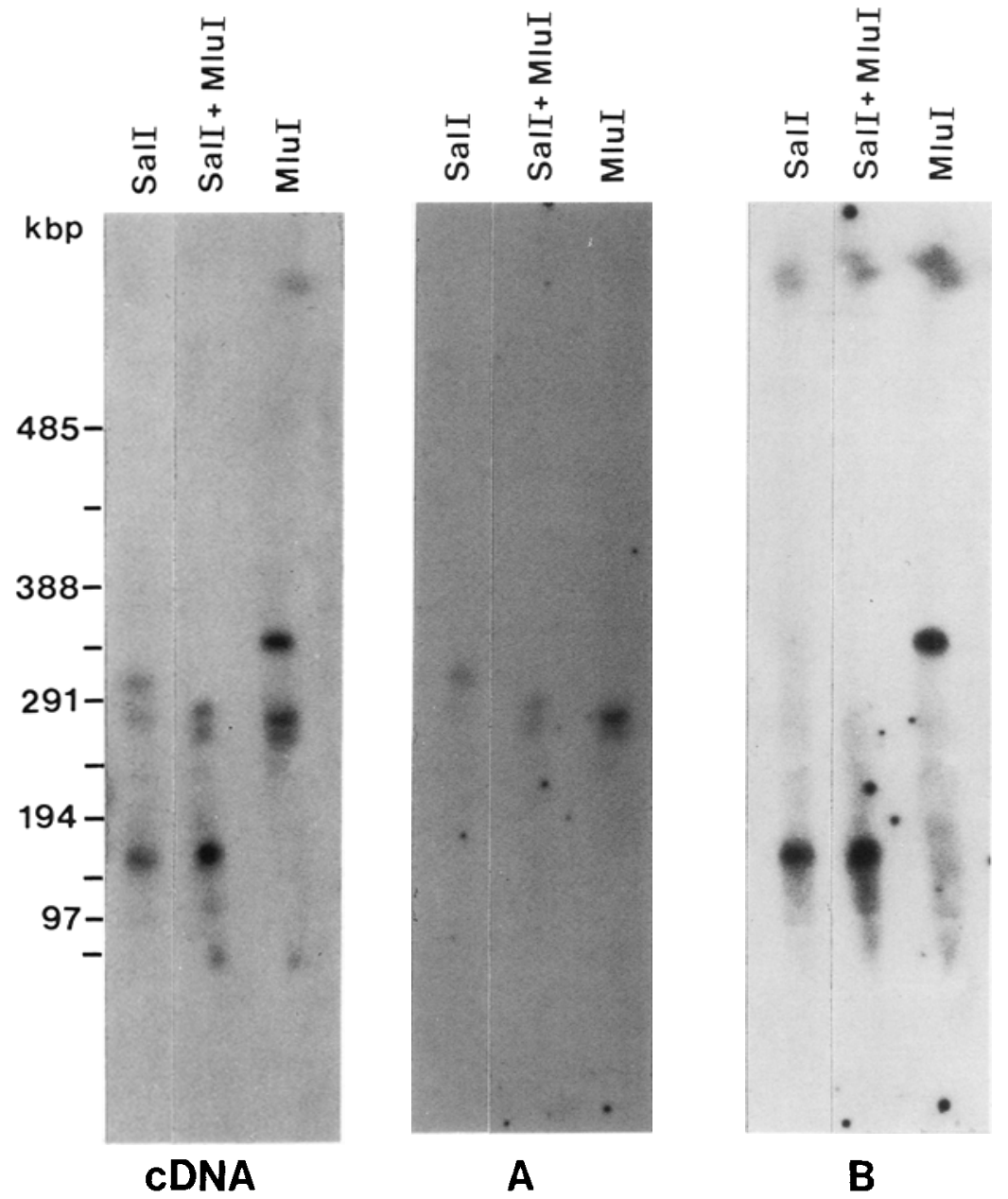

Figure 6. 'Waltzer' analysis of HMW barley DNA digested with Sall, MluI and SalI + MluI as indicated. Successive hybridizations were with pchor2-4 cDNA probe, probe A and probe B as indicated in Figure 1. Pulse length: 30 sec. 

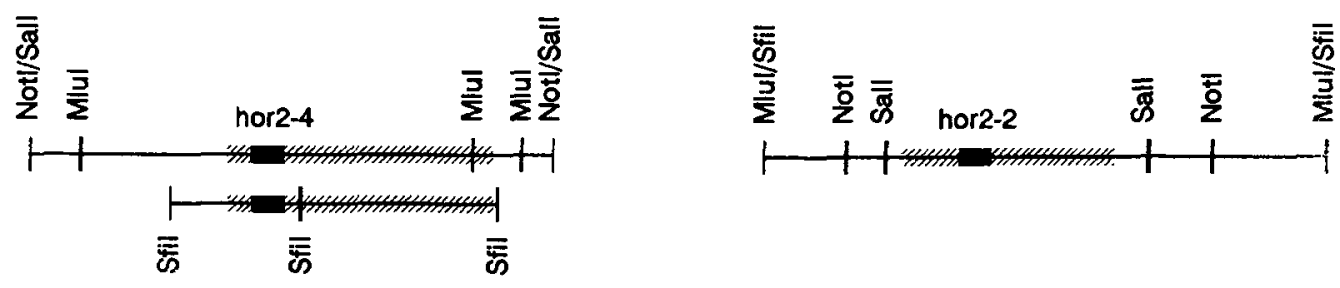

Figure 7. Map of the Hor 2 locus. The dashed areas indicate regions hybridizing to the pchor 2-4 cDNA probe, while the filled areas give the position of the hor 2-4 and hor2-2 genes. Fragment lengths are estimated from autoradiograms shown in Figures 4, 5 and 6 and at least two additional digests with each enzyme. The Sfil sites around the hor 2-4 gene are shown below the other sites indicating that the order is not known. The order of the sites separated by a dash $(/)$ has not been determined.

to both gene specific probes would provide evidence for the physical linkage of the genes. Limited digestion with MluI gives three hybridizing fragments of $400-500 \mathrm{kbp}$ in addition to the fragments seen in complete digests (results not shown). However, these partially digested fragments are too small to be the combination of the 270 and $345 \mathrm{kbp}$ MluI fragments. Larger SalI partials were detected with the cDNA probe, but the hybridization of these fragments was too weak to allow detection with the gene specific probes (results not shown).

The combined data from hybridization of single and double digests allows the construction of a map of the Hor 2 locus (Fig. 7). This map illustrates some interesting features of the Hor 2 locus which are revealed by the PFGE analysis. First, all the B-hordein genes are located within $360 \mathrm{kbp}$ of DNA, the locus being limited to the $200 \mathrm{kbp}$ SfiI and $160 \mathrm{kbp}$ Sall fragments. Secondly, the part of the locus containing the hor 2-4 gene is separated from the part containing the hor 2-2 gene by an unknown length of DNA.

\section{DISCUSSION}

The analysis of mammalian genomes by PFGE utilizes HMW DNA, which is isolated by embedding untreated cells in agarose. HMW plant DNA cannot be isolated in this manner, since plant cells are surrounded by a rigid cell wall. To overcome this problem, barley protoplasts were embedded in agarose and HMW
DNA subsequently recovered in a similar manner to mammalian HMW DNA. Methods have recently been published for the preparation and digestion of HMW DNA from Arabidopsis suspension cultures $(20)$ and tomato leaves $(10,18)$. These methods differ mainly from the one described in this study in the protoplast isolation procedure, as required by the differences in the starting material. The treatment of the protoplasts after embedding in agarose is similar for both Arabidopsis, tomato and barley.

So far, the only other analysis covering a large stretch of DNA in plants has been performed in tomato. In this plant, having a relatively small genome, PFGE has been applied with the purpose of establishing physical linkage to the $T m-2 a$ locus, located on chromosome 9 and conferring resistance to tobacco mosaic virus. Five RFLP markers placed within approximately $1.5 \mathrm{cM}$ of this locus were available for the study (46). PFGE analysis revealed close physical linkage of two of the markers by hybridization to the same $560 \mathrm{kbp}$ Sall fragment. Evidence for the physical distance between the three remaining markers was not obtained, but it was concluded that they are distributed over at least $3,000 \mathrm{kbp}$ of the chromosome (18). The large genome size makes the application of such an analysis to barley DNA less likely to be successful. In this study PFGE has been utilized to investigate the organization of multiple genes within a single genetic locus.

The confirmation of a close physical linkage 
between members of $\mathrm{Hor} 2$ and the construction of a map of $650 \mathrm{kbp}$ of DNA around the locus, is the first study of this sort in barley. In a few cases genomic walking (i.e. isolation of overlapping $\lambda$ clones) has been sufficient to establish physical linkage between members of multigenic loci. The ribulose bisphosphate carboxylate small subunits gene families in tomato (45) and petunia (11) comprising 5 and 8 genes, respectively, and the leghemoglobin gene family in soybean (2) containing 6 genes are examples where such an analysis has been successful. In all of these studies clustering of the genes has been demonstrated. Thus, the soybean leghemoglobin genes are located within two independent clusters of $40 \mathrm{kbp}$, containing 2 and 4 genes, respectively (2). However, the largest stretch of contiguously mapped DNA, in these studies, does not exceed $50 \mathrm{kbp}$ and the mapping is therefore still on a relatively small scale. Although a number of genomic $\lambda$ clones has been analyzed, none has been identified which contains more than a single B-hordein gene $(3,16$, BRENNER et al., unpublished). This indicates that the B-hordein genes are less tightly clustered than the members of the other plant multigenic families so far studied.

Previously the Hor 2 locus has been shown to extend over at least $80-90 \mathrm{kbp} \mathrm{(25)}$. This estimate was based on summation of the fragments hybridizing to a common B-hordein probe in a Southern blot of HindIII digested barley DNA. It indicates the minimum size of the locus since these fragments are not contiguous in the genome. PFGE analysis has restricted Hor 2 to two fragments of 160 and $200 \mathrm{kbp}$ giving a total size of $360 \mathrm{kbp}$ for the entire locus. The B-hordein genes may be clustered within part of these fragments, such that $360 \mathrm{kbp}$ is an overestimate of the actual size. However, the two sets of hybridizing fragments are not contiguous but separated by an unknown length of DNA, indicating a larger size or rather a division of $\mathrm{Hor} 2$ into two sub-loci. If this is the case each of these two subloci contains 5-8 B-hordein genes corresponding to approximately half of the total number, judged from the similar hybridization intensity of the two fragment classes in all the different digests.

The major B-hordein polypeptides in Carls- berg II barley endosperm are the B1 and B3 polypeptides with molecular weights of 30 and $38 \mathrm{kD}$, respectively. On the basis of coding capacity and alignment with peptide sequences the hor 2-4 gene was found to encode a B1 type hordein polypeptide (3). B3-hordein encoding genomic clones have hitherto not been identified, but two cDNA clones pB 11 and pB7 have, in hybrid-release translation experiments, been shown to encode B1 and B3 polypeptides, respectively (17). The partial sequence data available for the hor2-2 gene (BRENNER et al., unpublished) reveal that this gene aligns more closely with $\mathrm{pB} 7$ than $\mathrm{pB} 11$, indicating a gene of the $\mathrm{B} 3$ type. On the other hand the hor2-4 gene is equally homologous to $\mathrm{pB} 7$ and $\mathrm{pB} 11$ in this part of the gene. Sequence data alone are therefore insufficient to identify clones as either encoding B1 or B3 hordein polypeptides. A possible correlation between the two polypeptide groups and the two sets of hybridizing fragments identified with PFGE therefore awaits the identification of full-length clones encoding B3hordein polypeptides.

Establishment of techniques for isolation and digestion of HMW barley DNA is the first step towards cloning of large DNA fragments in yeast artificial chromosomes (YAC's) as described by BURKE et al. (5). Isolation and mapping of YAC clones containing the Hor2 locus or a part of it will reveal features of the gene organization within this locus, which cannot be shown by PFGE alone. Thus, the physical distance and relative polarity of individual genes could be studied without extensive genomic walking being necessary.

\section{ACKNOWLEDGEMENTS}

Dr. ANDERS BRANDT is gratefully thanked for thorough assistance throughout this work. This work was supported by the Biotechnological Action Programme of the Commission of the European Communities with contract no BAP0091.DK to Professor D. von WetTstein and H. G. SARX.

\section{REFERENCES}

1. Blake, T.K., S.E. UllRich \& R.A. NilaN: Mapping of the Hor3 locus encoding $\mathrm{D}$ hordein in barley. 
Theor. Appl. Genet. 63, 367-371 (1982)

2. Bojsen, K, D. Abildsten, E. Ø. Jensen, K. Palu. DAN \& KA. MARCKER: The chromosomal arrangement of six soybean leghemoglobin genes. EMBO J. 2, 1165-1168 (1983)

3. Brandt, A., A. Montembault, V.Cameron-Mills \& S.K. RASMUSSEN: Primary structure of a $\mathrm{Bl}$ hordein gene from barley. Carlsberg Res. Comm. 50, 333-345 (1985)

4. Brown, W.R.A.: A physical map of the human pseudoautosomal region. EMBO J. 7, 2377-2385 (1988)

5. BURKE, D.T., G.F. CARLE \& M.V. OLSON: Cloning of large segments of exogenous DNA into yeast by means of artificial chromosome vectors. Science 236, 806-812 (1987)

6. Burmeister, M., A.P. Monaco, E.F. Gillard, G.J.B. vaN. OMMEN, N.A. Affara, M.A. Ferguson. SMITH, L. M. KUNKEL \& H. LeHRACH: A 10megabase physical map of human Xp21, including the Duchenne muscular dystrophy gene. Genomics 2, 189-202 (1988)

7. Cameron-Mills, V. \& A. Brandt: A $\gamma$-hordein gene. Plant Molec. Biol. 4, 449-461 (1988)

8. CARLE G.F. \& M.V. OLSON: Separation of Chromosomal DNA molecules from yeast by orthogonalfield-alternation gel electrophoresis. Nucleic Acids Res. 12, 5647-5664 (1984)

9. CARLE, G.F. \& M.V. OLSON: An electrophoretic karyotype for yeast. Proc. Nat. Acad. Sci. 82, 3756-3760 (1985)

10. Daelen, RA.J. van, J.J.Jonkers \& P. Zabel: Preparation of megabase-sized tomato DNA and separation of large restriction fragments by field inversion gel electrophoresis (FIGE). Plant Molec. Biol. 12, 341-352 (1989)

11. Dean, C., P. van den Elzen, S. Tamaki, M. Black, P. DunsmuIR \& J. BEDBRoOK: Molecular characterization of the rbcS multi-gene family of Petunia (Mitchell). Mol. Gen. Genet. 206, 465-474 (1987)

12. DunNen, J.T. DEN, E. BAKKeR, E.G. KLeIN BRETELer, P.L. Pearson \& G.J.B. van Ommen: Direct detection of more than $50 \%$ of the Duchenne muscular dystrophy mutations by field inversion gels. Nature 329, 640-642 (1987)

13. EDWARDS, G.E., S.P. ROBINSON, N.J.C. TYLER \& D.A. WALKeR: Photosynthesis by isolated protoplasts, protoplast extracts and chloroplasts of wheat. Plant Physiol. 62, 313-319 (1978)

14. FAULKS, A.J.,P.R. SHEWRY \& B.J. MIFLIN: The polymorphism and structural homology of storage polypeptides (hordein) coded by the hor 2 locus in barley (Hordeum vulgare L.). Biochem. Genet. 19, 841-857 (1981)

15. Feinberg, A.P. \& B. Vogelstein: A technique for radiolabelling DNA restriction endonuclease fragments to high specific activity. Anal. Biochem. 132, 6-13 (1983)

16. Forde, B.G., A. HeYworth, J. PYWELl \& M. KREIS: Nucleotide sequence of a $B 1$ hordein gene and the identification of possible upstream regulatory elements in endosperm storage protein genes from barley, wheat and maize. Nucleic Acids Res. 13, 7327-7339 (1985)

17. FoRDE,B.G.,M.KREIS, M.S. Williamson,R.P.FrY, J. Pywell, P.R. Shewry, N. Bunce \& B. J. Miflin: Short tandem repeats shared by B- and C-hordein cDNAs suggest a common origin for two groups of cereal storage protein genes. EMBO J. 4, 9-15 (1985)

18. Ganal, M.W., N.D. Young \& S.D. TANksLeY: Pulsed field gel electrophoresis and physical mapping of large DNA fragments in the $T m-2 a$ region of chromosome 9 in tomato. Mol. Gen. Genet. $215,395-400$ (1989)

19. GIESE, H. \& H.E. HoPP: Influence of nitrogen nutrition on the amount of hordein, protein $Z$ and $\beta$-amylase messenger RNA in developing endosperms of barley. Carlsberg Res. Comm. 49, 365-383 (1984)

20. GUZMAN, R. \& J.R. ECKER: Development of large DNA methods for plants: molecular cloning of Arabidopsis and carrot DNA into yeast. Nucleic Acids Res. 16, 11091-11105 (1988)

21. HOPP, H.E., S.K. RASMUSSEN \& A. BRANDT: Organization and transcription of $B 1$ hordein genes in high lysine mutants of barley. Carlsberg Res. Comm. 48, 201-216 (1983)

22. HUGHeS, B.G., F.G. WHITE \& M.A. SMITH: Effect of plant growth, isolation and purification conditions on barley protoplast yield. Biochem. Physiol. Pflanzen 172, 67-77 (1978)

23. JENSEN, J., J.H. JøRGENSEN, H.P. JENSEN, H. GIESE \& H.DOLL: Linkage of the hordein loci horl and hor2 with the powdery mildew resistance loci $M l-k$ and Ml- $a$ on barley chromosome 5. Theor. Appl. Genet. 58, 27-31 (1980)

24. Kannangara, C.G., S.P. Gough, B. Hansen, J.N. RASMUSSEN \& D.J. SIMPSON: A homogenizer with replaceable razor blades for bulk isolation of active barley plastids. Carlsberg Res. Comm. 42, 431-439 (1977)

25. KREIS, M., P.R. ShewRY, B.G. Forde, S. RAHMAN \& B.J. MIFLIN: Molecular analysis of a mutation conferring the high-lysine phenotype on the grain of barley (Hordeum vulgare). Cell 34, 161-167 (1983)

26. Lawrance, S.K, C.L. Smith, R. SRivastava, C.R. Cantor \& S.M. WeIssman: Megabase-scale mapping of the HLA gene complex by pulsed field gel 
electrophoresis. Science 235, 1387-1390 (1987)

27. MCClelland, M. \& M. Nelson: The effect of site specific methylation on restriction endonuclease digestion. Nucleic Acids Res. 13, r201-r207 (1985)

28. Michiels, F., M. Burmeister \& H. Lehrach: Derivation of clones close to met by preparative field inversion gel electrophoresis. Science 236, 1305-1308 (1987)

29. Netsvetaev, V.P. \& A.A. Sozinov: Linkage studies of genes Glel and $H r d F$ in barley chromosome 5 . Barley Genet. Newsl. 12, 13-18 (1982)

30. OKunO, T.\& I. FuRUSAWA: A simple method for the isolation of intact mesophyll protoplasts from cereal plants. Plant Cell Physiol. 18, 1357-1362 (1977)

31. PoustKa, A., T. Pohl, D.P. Barlow, G. Zehetner, A. Craig, F. Michiels, E. Ehrich, A.-M. Frischauf \& H. LEHRACH: Molecular approaches to mammalian genetics. Cold Spring Harbor Symp. Quant. Biol. 51, 131-139 (1986)

32. Poustka, A., T.M. Pohl, D.P. Barlow, A.M. FRISCHAUF \& H. LEHRACH: Construction and use of human chromosome jumping libraries from NotIdigested DNA. Nature 325, 353-355 (1987)

33. Rahman, S., M. KReIS, B.G. Forde \& P.R. Shewry \& B.J. MIFl.IN: Hordein-gene expression during development of the barley (Hordeum vulgare) endosperm. Biochem. J. 223, 315-322 (1984)

34. RAPPOLD, G.A.\& H. LEHRACH: A long range restriction map of the pseudoautosomal region by partial digest PFGE analysis from the telomere. Nucleic Acids Res. 16, $5361-5377$ (1988)

35. Rasmussen, S.K \& A. BRANDT: Nucleotide sequences of cDNA clones for C-hordein polypeptides. Carlsberg Res.Comm. 51, 371-379 (1986)

36. Rasmussen, S.K., H.E. Hopp \& A. BRandT: Nucleotide sequences of cDNA clones for B1-hordein polypeptides. Carlsberg Res. Comm. 48, 187-199 (1983)

37. REED, K.C. \& D.A. MANN: Rapid transfer of DNA from agarose gels to nylon membranes. Nucleic Acids Res. 13, 7207-7221 (1985)

38. SChWARTZ, D.C. \& C.R. CantoR: Separation of yeast chromosome-sized DNAs by Pulsed Field Gel Electrophoresis. Cell 37, 67-75 (1984)

39. Shewry, P.R., M. Kreis, S. Parmar, E.J.L. LeW \& D.D. KASARDA: Identification of $\gamma$-type hordeins in barley. FEBS Lett. 190, 61-64 (1985)

40. Shewry, P.R., A.J. Faulks, R.A. Pickering, L.T. JONES, R.A. FINCH \& B.J. MIFLIN: The genetic analysis of barley storage proteins. Heredity 44, 383389 (1980)

41. Shewry, P.R. \& S. Parmar: The HrdF(Hor5) locus encodes $\gamma$-type hordeins. Barley Genet. Newsl. 17, 32-35 (1987)

42. Smith, C.L., T. Matsumoto, O. Niwa, S. KlCo, J.B. FAN, M. Yanagida \& C.R. CANTOR: An electrophoretic karyotype for Schizosaccharomyces pombe by pulsed field gel electrophoresis. Nucleic Acids Res. 15, $4481-4489$ (1987)

43. Sørensen, M.B., V. Cameron-Mills \& A. Brandt: Transcriptional and post-transcriptional regulation of gene expression in developing barley endosperm. Mol. Gen. Genet. 217, 195-201 (1989)

44. SOUthern, E.M., R. ANand, W.R.A. Brown \& D.S. FLETCHER: A model for the separation of large DNA molecules by crossed field gel electrophoresis. Nucleic Acids Res. 15, 5925 (1987)

45. Sugita, M., T. Manzara, E. Pichersky, A. CashMORE \& W. GRUISSEM: Genomic organization, sequence analysis and expression of all five genes encoding the small subunit of ribulose-1,5-bisphosphate carboxylase/oxygenase from tomato. Mol. Gen. Genet. 209, 247-256 (1987)

46. Young, N.D., D. ZamiR, M.W. Ganal \& S.D. TANKSLEY: Use of isogenic lines and simultaneous probing to identify DNA markers tightly linked to the Tm-2a gene in tomato. Genetics $120,579-585$ (1988)

Accepted by E. LUND 